\title{
Emerging Adulthood in the Historical Life-story Study of Finnish Writer Arvi Järventaus in Lapland
}

\author{
Outi Oinas \\ Ph.D., University lecturer (emerita) \\ Faculty of Education, University of Lapland \\ P.O. Box 122, 96101 Rovaniemi, Finland \\ E-mail: a.a.oinas@pp.inet.fi \\ Kaarina Määttä (Corresponding author) \\ Professor of Educational Psychology \\ Faculty of Education, University of Lapland \\ P.O. Box 122, 96101 Rovaniemi, Finland \\ Tel: 358-400-696-480Ｅ-mail: Kaarina.Maatta@ulapland.fi
}

Received: March 24, 2011 Accepted: April 10, $2011 \quad$ doi:10.5539/res.v3n1p35

\begin{abstract}
The aim of this article is to consider the modern theories of Cultural Approach and Emerging Adulthood, developed by Dr. Jeffrey Jensen Arnett, in qualitative history-oriented research. This article looks at the biographic study of a Finnish author's and clergyman's first forty years of life in north Finland during 1883-1923. The object person is Arvi Järventaus, the first storyteller in Finnish Lapland. The research questions, bearing the cultural approach in mind, focused on Järventaus's development during lifespan periods in two major lines as follows: 1) how his religious convictions changed during the years of emerging adulthood and 2) how his social philosophical values changed as a result of the historical events he experienced during that period. Methodologically, this study relies on linguistic tradition, a careful choice and analysis of the texts and novels of Järventaus together with the documents he left behind. What is known about emerging adults in America today is compared with the unknown lives and mentalities of an era more than a hundred years ago in northern Scandinavia.
\end{abstract}

Keywords: Historical biography, Internal emerging adulthood, Arnett, Cultural approach, Resilience

\section{Introduction}

How people understand the past is always connected to how they understand the future. In this article, we endeavor to survey possibilities that contribute to the modern theories of Cultural Approach and Emerging Adulthood, developed by Dr. Jeffrey Jensen Arnett, in qualitative-history-oriented research seemingly alien to the research situation of today. We also hope the article provides a good sounding board for life-story researchers, encouraging them to benefit from quantitative and recent research on what is known about the period called emerging adulthood and its impact on the future. The integration of the past and present is presented and illustrated through a lifespan study that used the developmental psychology lifespan theories as tools and thus as a servant in the structural outline as well as in the analysis of the historical data. What is known about emerging adults in America today is placed in connection with the unknown lives and mentalities of an era more than a hundred years ago in northern Scandinavia. The difficulties in a man's search for resilience due to his years of emerging adulthood are referred to here as years of internal emerging adulthood.

Historical qualitative studies are rarely, if ever, connected with studies on "emerging adulthood". The concept in its present meaning is fresh: it was first launched in 2000 by Dr. Jeffrey Jensen Arnett. The very attraction of Emerging Adulthood theory, however, lies in the insight and respect the theorist sets on research tradition integrated in history, especially on G. Stanley Hall, whose education dated back to Greek philosophers (Arnett, 
1999; Arnett \& Cravens, 2006). Old theories emerge as new with respect and regard for the past. Hall, Piaget, Erikson, Levinson, Havighurst and Arnett all share an interest in human development found in periods of life, arguing to what extent the features found could be understood as universal. We suggest here a return to the historic view, asking to what extent features found in a historical life story could be universally valid.

Emerging Adulthood, as defined in 2000, was not supposed to have existed in cultures where people married early, settled down young and took on responsibilities as soon as physically possible. It was presented to be a phenomenon of wealthy societies from the past 50 years onward (Arnett, 2000). But when studied in more and more cross- inter-and multidisciplinary terms, the context of the idea tends to refer to a man's inner experience emphasizing less what seemingly adult steps in life he has taken before or during the years concerned (Arnett \& Tanner, 2006). The Emerging Adulthood theory has focused on ages 18 to 25-30 as a period that is neither adolescence nor young adulthood but distinct from both. Our findings presented in this article suggest that the phenomenon of prolonging adolescent years could bear features rooted in human lives in historic times despite the cultural or socio-economic environment.

Research on the subject matter is called for in today's Europe and America. Politicians are worried about delayed adulthood in Scandinavian countries, including Finland. Officials are also puzzled by the increasing mental health problems of emerging adults returning from service in faraway crisis societies. The vulnerability of a man during his emerging adulthood can be verified in medical data gathered from several wars, historical and recent (Rosenthal, 1991; Rotchild, 1998; Tuomaala, 2008).

Life stories are bound to carry on a wide range of traditions (linguistic, literary, historical, social, educational, psychological), and even the philosophy of religion seems an overlooked source of knowledge. They become scientifically interesting, if they manage to promote something more than an object person's life course. We will introduce here the concept of "internal emerging adulthood" to distinguish it from "emerging adulthood" of the present research situation.

Why not allow past generations' experience to talk as well?

\section{Historical Framework}

The historical environment studied in the sample life story of this article is an overlooked era, alien to theorists as well as readers of this journal: northern Scandinavia, Lapland in Finland, during the crucial years in Finnish history around and about a hundred years ago. The era seems to include all the elements that millions of people are experiencing today in societies that are changing from stability toward violence or from one cultural environment to another. The period allows keen observation of the impact of political and social turbulence on the growth and development of the young at the time. Religious and social values are tested during struggles for independence and extended to fatal choices about what could be the best constitution for the object person's country. The winners as well as the losers grow up suffering from the consequences of a cruel civil war in the heat of their young years. It leaves them as well as their society, the independent parliamentary Finland, coping with the challenge of resilience.

\section{The Object Person in Finnish History}

Our article looks at the biographic study of an author and clergyman's life in north Finland during 1883-1923 (Oinas, 2008). The study focuses on the first forty years of the life of Arvi Järventaus (1883-1939), a clergyman and the first storyteller in Lapland to write in the Finnish language. Järventaus served in several parishes in the province until 1923. Thus, the period allows researchers to evaluate the influence of his adolescence and emerging adult years on his adulthood. At the age of 40, he left Lapland. His life experiences are reflected in novels, plays, sermon collections, poetry and even political pamphlets. He left a massive, unorganized archive under the auspices of the Society of Finnish Literature. Some of his 27 published novels-last editions by WSOY (Werner Söderström Corporation) in 1990 - have been translated into Swedish, German and Hungarian (Korhonen, 1975; Oinas, 2008). Järventaus's works were reported on, critiqued and commented on in tens of newspapers and magazines during his lifetime, mostly outside the academic tradition. His works were read and studied as Barthesian texts without interest in the writer as an individual (Note 1). After his death in 1939, the postwar critics defined him in literary histories either as an exotic Lapland enthusiast or a national extremist. For some literary critics, he was an author who deserved to be forgotten; for others, he deserved to be praised for opening up Lapland and Lapp people, the Sami, and the Fenno-Ugric language family to cultural and political discussion. For the latter, he was nominated as an honorary doctor at the University of Debrecén in Hungary in 1938.

The prominent literary tradition was not to interpret or to explain, not to mingle the author's personality with his 
works. "Work" was not even the word to be used. The proper word for "book" was "text." Nor was the clergyman fit to be connected with any message other than his religious cause (Kähkönen, 1989, p. 287). The life-story study of Järventaus set out to awaken the very person from the dead, unwrap a mummy and allow his life speak for him through his texts together with the documents he left behind.

\section{Cultural Approach}

Methodologically, it was obvious that a study of any past era would need tools to cope with cultural contexts and cultural conflicts. An individual born into a certain cultural beliefs system would meet with others as he widened his scope of life. Dr. Arnett's theory of observing family cultures from the aspect of how broad or narrow a framework they set for the limits and restrictive features leading to normative behavior attracted us, although the kinds of creative stimulation, freedoms of choice, schooling available, i.e., life conditions, were in different cultural contexts in the class society under study (1883-1923) from those the theory was created for (Arnett, 1995). The theory as it was formulated in the English language was not meant to include ranking of cultures regarding their moral values. But when adapted to the Finnish semiotic context, the theory seemed to imply that some cultural frameworks allow broader-minded, i.e., more blessed environment, for one's growth to broad-minded adulthood than the limiting ones that tend to leave people narrow-minded. Both adjectives include labeling related to cultural values. Historians use the term "mentalities" instead of "cultures" to describe what is common to a person and those of his time. Microhistorians look for anomalies and ontological clues to reveal the mentalities (Davis, 1987, 2001; Ginzburg, 2007). In the Järventaus study where fictive novels formed part of the data, the method respected everything that would show how Järventaus experienced himself, culturally, socially and politically. Our adoption of the cultural approach seemed a welcomed, more individual-centered tool than any based on mentalities. However, the adoption made us by and by set the terms broad and narrow in the background. The approach was to be expressed in more delicate words to describe individuals in religious or political environments. We were, however, grateful for the theory for having made us linguistically alert and critical, which was the purpose of the cultural approach (Arnett, 2002). The sensitivity on choices of expression made us try to create supplementary expressions such as spacious, wide, less authoritative/dominative, restrictive, but once presented, the cultural approach was there to stay regardless of our less coherent expressions.

\section{Research Questions and Method}

The research questions, bearing the cultural approach in mind, focused on Järventaus's development during lifespan periods in two major lines as follows: 1) how his religious conviction changed during the years of emerging adulthood and 2) how his social philosophical values changed as a result of the historical events he experienced during that period of life.

Methodologically, the study relied on linguistic tradition, a careful choice and analysis of data. Linguistic and analytical awareness is necessary, especially in a life-story study: the mute material is brought alive in the form of another story, a story created by the researchers. As Natalie Zemon Davis has pointed out, it is one story among many possible ones and never a final truth (Davis, 1987). The analysis is a living structure that should do justice to the object person. The language should be no code language, which the scholar suffers a while, feels uneasy and quickly leaves behind, when his task is fulfilled. To be fair and just, the researcher needs the distance that a theoretical tool can supply him with, but he must feel fair using it. The very aspect of "socialization" was put aside when defining the research questions bearing cultural aspects in mind.

\section{A Brief Biography}

Järventaus grew up in a poor railway smith's family filled with the fear of God and bourgeoning awareness of a unique national identity. At the time of his birth, his country, formerly Sweden's Province of Finland, which, due to the Napoleonic Wars of 1808-1809 between Sweden and Russia, had for years been peacefully living in symbiotic autonomy with Russia as the Grand Duchy of Finland, was at peace "satisfied with its position" (Finland's president Mr. Koivisto in 2000). The country had successfully claimed its liberal western European constitutional rights from the times of the Swedish kings. Finland was a conquered country that was never a province in the Russian Empire in terms of common language or laws. During Järventaus's youth, however, historical events led to fierce opposition aroused by demands for ultimate political changes. During Nicholas II's rule, all forms of national separatist tradition were considered dangerous "disobedience" against virtuous "obedience to the Emperor." Järventaus and his contemporaries grew to consider the Tsar a traitor of his predecessors' promises.

As Järventaus was granted an allowance to study at the famous classical lyceum in Oulu, later at the University in Helsinki, his years of study were spent in political turbulence over the previously respected national rights. Young people shared the separatist rebellion process with adults. They called themselves "revolutionaries," 
refused to join the Russian army and welcomed the general strike in 1905. In Järventaus's life, the process led him toward radicalism. Although after graduation in 1908 Järventaus got immediately and conventionally married, he unconventionally chose posts in northern parishes far from governmental guidance. He acted like a refugee from the governmental problems. The government did not, however, leave him in peace. In Lapland, he refused to host the Tsar's Governor General, who inspected his community, risking being sent to Siberia. In the northern parishes, he also preached, in both the Finnish and Sami languages, a substantially more liberal concept of Christianity than that of laymen preachers of the Laestadian revivalist movement or even his official church, the Lutheran State Church of Finland. He felt sympathy with the Sami, many of whom still nourished old traditions and beliefs despite outside pressure to deprive the people of their way of life (Kähkönen, 1989). Finally, he gave up trying to fulfill expectations of behaving like a conventional clergyman. His participation in two wars in his time, the civil war in 1918 and the attempt to join part of the Kola Peninsula to Finland in 1920 was considered reckless behavior among the northern revivalist movement in all his northern parishes. In his southern parish in Tuusula he enjoyed mutual understanding with the contemporary artist society dwelling there, but was less appreciated by the conventionalists in the church.

\section{Cultural Tension as a Source of Creativity}

Observed from the cultural angle, his education became the turning point in Järventaus's life course. The very step from an urban industrial home environment into an upper-class classical school and university was in immense step into an alien culture, a step away from the working class's strict religious beliefs, a socially limited reality restricted by poverty. This could be seen as a step from the narrow cultural environment to the broad. But he himself used more neutral terms. He considered himself "a man of two worlds." He felt he had "betrayed" his equals in childhood after entering "the luckier world," where he was one among those who were allowed to learn languages and philosophy. But by no means did he admit to have forgotten his family background. He loved and respected his parents. At the time of war, he did not believe in the socialists' cause, but the fact did not separate him from his brothers who did. He was stunned and deeply disturbed in a traumatic situation. He had become a trustee of those who believed in Finland's nationalistic, parliamentary future as an independent nation, one of those who could not rely on the kind of atheist socialism offered by Lenin. Järventaus believed he was privileged to believe so.

Järventaus admired rebellious behavior, if it was emphasizing cultural values of one's own. In his northern parishes, there was a constant tension between Finnish laws and religious orientations with those of the Lapps. He stood for the Lapps, the Sami (see Kähkönen, 1989). Most of Järventaus's Lapland novels were initiated during his emerging adulthood in Lapland. In his novels, some of which were based on lawsuits in history, he described the Sami as dignified, peace-loving people who were not treated with due respect. He also openly opposed religious Laestadian revivalist (restricting) authority over them in his preaching. He himself was constantly confronted with similar demands. Lapps borrowing reindeer from others was not "stealing" to him but a crime in the eyes of the law. He refused to condemn it as "sin" in the novel Synnin mitta (Engl. The measure of sin, Järventaus, 1917). He respected the Lapps' human rights as ingenious people. He described the wordless anger of a Lapp child when he was deprived of his leather clothing in an orphanage, forbidden to sing "joiku," forbidden to speak the Sami language, all symbols of identity. Järventaus respected the identity of man regardless of culture (Järventaus, 1921; 1925). In doing so, he lacked the shelter and support of the discriminating society of his time (Järventaus, 1922; see Arnett, 2002). He loved to turn the serenity of his parishioner's conduct upside down in humorous tales (Järventaus, 1920; translation 2010).

Järventaus's religious beliefs and social values changed when he fought his way to adulthood, but was it the tension between "the two worlds" rather than cultural belief systems and normative expectations that brought about the change? Interestingly, his religious beliefs became more liberal, tolerant and finally searching global ethics, but his socio-political nationalist views grew stricter in the supposedly more sophisticated world of education during the years of emerging adulthood. It took him almost a lifetime to return to understanding.

His coping strategy was to deal with his internal tensions creatively: if he acted the way he was expected to do in his educated world, then he reflected the actions and analyzed alternatives in his books. The books in which he describes his childhood and adolescence made us wonder. His religiously restrictive, narrow, background culture had surrounded him with extraordinary personalities and varying life conditions, but mainly because he himself was observant. He looked at human weaknesses with a sense of humor and warmth, but with irony toward the pompous and the self-righteous and toward himself: "He was the kind of naive creature bound to be stepped on." (Järventaus, 1923; 1927; 1928).

The phenomenon on which we base the term internal emerging adulthood was seen in the object person's quality 
of change. First, the cultural changes that influenced Järventaus's actions were imposed upon him from outside, from school and political atmosphere, from the church. An adolescent wished to be accepted by his fellows and was therefore adoptive (Aristotle in Hall's language, 1904). Second, he himself worked the changes from within as an average emerging adult. Yet emerging adulthood did not seem to end in resilience, although his feelings and thoughts in his writings yearned for resilience. To understand why, we turned to the microhistorian method of finding clues from anomalies.

What he did not write down or publish was important, because it reflected trauma-a change too hard to cope with. Both of the wars that he participated in seem to have caused trauma (Laufer, Frey-Wouters, \& Gallops, 1985; Rosenthal, 1991; Rotchild, 1998; Tuomaala, 2008). The changes in his convictions together with the trauma formed tension to the point of post-traumatic stress. That being accepted, cultural tensions seemed to have turned into a cultural blessing. He appeared to have solved the tensions between his background culture and his later duties and actions in his literature.

\section{Emerging Adulthood Re-considered}

\subsection{Similarities and differences in modern and historical emerging adult lives}

What are the acknowledged features in personality development that are present in change? Based on storm and stress views (Hall, 1904; Arnett, 1999) and what is known about the period of Emerging Adulthood today, theorists emphasize the role of one's inner experience of oneself in present-day American college students' lives in seminars and reports (Arnett \& Tanner, 2006). Hall's views of storm and stress in adolescence are re-evaluated, depicting them as more nuanced with views on cultural variations and individual differences in Arnett's and his colleagues' studies to confirm that there is a constant need of reframing theories to meet the challenges of changing times. But how different are the times from the individuals' point of view?

The official year of adulthood is 18 today. It was 21 in Järventaus's times. European college students today graduate at the age of 25 , and so did Järventaus. That covers the modern-view years on emerging adulthood. The average age of graduation in Finland is even higher, one of the highest in Europe, 281/2 years. Feelings about oneself a century ago seem to bear features of confusion similar to those of today's emerging adults. So do the other criteria.

The years of emerging adulthood are described as the age of identity explorations, the age of instability, the age of feeling in-between, the self-focused age and the age of possibilities (Arnett, 2000; Arnett \& Tanner, 2006; Arnett, 2007a, 2007b). The last seems to reveal a crucial difference in Arnett's theory from the earlier theories. Arnett and his colleagues contribute to studies on moral development, self-understanding and affective changes searching for positive outcomes, relying on cognitive development, re-centering and resilience. These theorists do not see development as deeply rooted in earlier experiences or choices, as most of their predecessors do. The theory opposes the claim for systematic problem-solving demands (Erikson's remarks, 1968). Risk behavior is not doomed to be everlasting. However, it can turn to affect the rest of one's life if the development of cognitive skills is interrupted. People get hold of their lives, because their cognitive skills and adaptive resources keep developing during emerging adulthood. Continuing identity explorations help develop coping strategies. Self-focused problem-solving capacities allow growing flexibility. Did any of that occur in the historical life story?

Järventaus's (and his peers') emerging adulthood seemed to skip several of the features described above. His adolescent years were full of storm and stress, but the storm and stress were not directed at his parents or cultural background but at the outside rule. The emphasis allowed no real identity explorations at the normal age of instability, because the adolescents copied and adapted the ideals that were forced upon them from adults outside. It was not his cultural background that made him behave recklessly toward his superiors such as the Governor General. Recklessness was a code of conduct that was expected from him by his peers as well as his educators. Recklessness was normative, a duty and a coping strategy at the same time. No feeling of in-between was allowed: only bold and immediate jumps into adulthood such as early marriage, job, children and responsibilities. Development of cognitive skills was postponed because of outer crises.

But interestingly, the identity explorations, feelings of in-between, instability and self-focused ponderings pop up in the literature initiated during the emerging adult years, or written down later about the times of his emerging adulthood: playing roles, changing identities, taking part in adventurous trips in the deserts, sleighing down mountains on bearskin (Järventaus, 1916). The author also set out to try his limits as to how far he could stretch the patience of his employers by being a non-conformist and still keep his job (Järventaus, 1922). He showed prolonged feelings of in-betweenness. It was easier to express the feelings through his characters than in real life. "Get out of my way, all you who build dams in my flooding streams of youth" was text from the pen of a 
married man who was responsible for a vast parish, a wife and seven children (Järventaus, 1928). "Theology did not manage to kill life," he wrote, when his reality was spending his life in frozen churches. "Outside the church there were lilies in blossom." (Järventaus, 1923.) The very meaning of literature in the data can be seen to verify human development as a hiding place for real feelings. The cognitive skills and flexibility that he was not able to show in real life were proved in the conduct of his characters, their thoughts and doubts, compassion and hatred, but also in the metaphor. Cultural differences also point in the same direction. Because of his cultural background, Järventaus was able to feel empathy toward his opponents after the miseries of the civil war, whereas many of his peers, even his wife, could not. He had spent his age of possibilities fighting for the causes he saw as right.

Seen through literature, the period of emerging adulthood was extended way out of its proportion for search for inner peace and resilience. We interpret that an author is closer to adulthood each time he finishes a novel. The understanding of emerging adulthood as a distinct period of life can be seen to justify the author, both in literature and in life. If so, a historical study with the lifespan theory is not a vain effort.

\subsection{Resilience}

The end of Järventaus's life was filled with fear of another threatening war. In 1937 he wrote in a book dealing with one bloodier period in Hungarian history: "Why didn't anyone grasp the great spade called Love, or the sword named Faith...Faith, regardless of religion and Love, despite differences of opinion" (Järventaus, 1937). The situation in Hungary in 1938 prophesized a deepening economic and social crisis between globalists and nationalists. "My darling", Järventaus wrote to his wife on the way back to Finland from Austria where Germans had simply marched in "I cannot like these Germans! Their nature yearns for war. Whom they eat, they swallow. I easily understand that they are afraid in Hungary. Not to talk about the Czech (letter from Vienna, Austria 24th of April)". Järventaus saw Hitler's army marching on the 1st of May 1938 in Berlin. He was terrified to see the lack of individualism in faces of the soldiers, the pompousness of the scene and the sounds. He had a manuscript on Hungarian experiences in his portfolio to be brought home to his publisher. There was criticism of the global Jewish impact on the Hungarian economy in the manuscript. From his heart's content, he added his discussions with a humble Jewish rabbi. At the end, he wrote: "It is divine to understand one another" (Järventaus, 1939). Home, he wrote to his wife: "God bless Finland!" (an open postcard from Berlin, 1st of May, 1938). Järventaus had found resilience, at last. That was a year before he died in 1939. In Järventaus's case, the optimism in the lifespan theory proved true, after all, but nothing saved the world from another world war, numbered II.

\subsection{Ponderings}

There are plenty of those who reject the very idea of arguing human experience during the periods of life as something universal and inevitable. This thesis presented an example of how one of the periods, "Emerging Adulthood", has been used as a tool and framework in a historical lifespan study, suggesting that this period is also meaningful in a historical life, way back in time. The analysis of the study set out to ponder whether it is possible to integrate a historical cultural context with a modern theory meant to be used in modern connections. During the course of the study, we were amazed at the essentials where the lifespan theory was leading the life story. The research had posed and answered the questions. The theoretical framework saved the study from becoming a mere story. The study suggests the following:

1) Young people did not reach psychologically resilient adulthood a century ago any earlier than they do now. The concrete choices (marriage, parenthood, full-time work) were forced upon emerging adults as normative expectations, but features found in emerging adults' thinking processes were there in the form of internal emerging adulthood. The long winding road to adulthood was hidden in the emerging adults' minds. The emerging adults' lack of space to express themselves came up in literature, art and music (in Finland, Leino, Edelfeldt, Schjerfbeck, Sibelius).

2) The cultures and mentalities of the era strongly influenced changes in values.

3) There was no freedom as understood today, but most certainly there were storm and stress, confusion and fearfulness for the future.

\section{Conclusions}

The theory of Emerging Adulthood as a distinct period of life, a new life stage, as well as the cultural approach attached to the period are excellent instruments even when not the focus of a study. The Cultural Approach does not fade away in changes in expression. The terminology used in the theory of Emerging Adulthood is well justified at any historic time. The features cannot be proved universal based on one life story, but they appear to be consequences of historical and cultural conditions. Thus, the theories open new visions to influence life 
conditions, to prevent violence.

The anomalies in life stories point at traumatic experiences due to war-time experiences. This phenomenon is similar in veterans' life stories about their emerging adult years all over the world no matter what era in history. The abundance of quantitative research reinforced by qualitative lifespan studies should convince the world politicians of the vulnerability of man's mind in emerging adulthood years. The emerging adults are enthused volunteers for peace-making purposes that wars are justified with. As Aristotle put it in the 4th century BC: "The young are prone to desire, they may have formed into action." Or in Hall's words, "Their lives are lived in hope." Their future, however, relies on how their emerging adult years allow these young adults to develop their adaptive skills in peace. Historical lifespan studies are there to promote understanding of the consequences of violently delayed development. "The tulip-flower does not grow faster if pulled."

Literature reflects the voices missing.

\section{References}

Arnett, J. J. (1995). Broad and narrow socialization: The family in the context of a cultural theory. Journal of Marriage and Family, 57 (3), 617-628.

Arnett, J. J. (1999). Adolescent storm and stress reconsidered. American Psychologist, 54 (5), 317-326.

Arnett, J. J. (2000). Emerging adulthood. A theory of development from the late teens through the Twenties. American Psychologist, 55 (5), 469-480.

Arnett, J. J. (2002). Adolescence and emerging adulthood. A cultural approach. Upper Saddle River, N.J.: Pearson Prentice Hall.

Arnett, J. J. (2004). A longer road to adulthood, in A Winding Road from Late Teens though their Twenties. [Online] Available: http://www.jeffreyarnett.com/articlesEABOOK2004ch.pdf (November 11, 2009).

Arnett, J. J. (2007a). The international encyclopedia of adolescence. (Vol. No. 1). New York: Routledge.

Arnett, J. J. (2007b). Adolescence and emerging adulthood, cultural approach. Clark University: Prentice Hall.

Arnett, J. J., \& Cravens, H. (2006). G. Stanley Hall's adolescence. A centennial reappraisal. History of Psychology, 9(3), 165-171.

Arnett, J. J., \& Tanner, J. L. (Eds.) (2006). Emerging adults in America coming of age in the 21st century. (Vol X). Washington DC: American Psychological Association. [Online] Available: http://www.alli.fi/sivu.php?artikkeli/ id=17 75k (April 8, 2000).

Davis, N. Z. (1987). Fiction in archives. Pardon tales and their tellers in the sixteenth century France. California: Stanford University Press.

Davis, N. Z. (2001). Martin Guerren paluu [The return of Martin Guerre]. (Transl. A. Vuola.) Tampere: Gaudeamus.

Erikson, E. H. (1968). Identity, youth and crisis. New York: Norton.

Ginzburg, C. (2007). Juusto ja madot. 1500-luvun myllärin maailmankuva. [The Cheese and the worms: The cosmos of a Sixteenth century miller]. (Transl. A. Vuola.) Helsinki: Gaudeamus.

Hall, G. S. (1904). From adolescence: Its relation to psychology, anthropology, sociology, sex, crime, religion, and education. Vols I \& II. In J. J. Arnett (Ed.). (2007). Readings on adolescence and emerging adulthood. History of adolescence (pp. 1-5). Englewood Cliffs, NJ: Prentice Hall.

Kähkönen, A. (1989). Kirkko ja saamelaisväestö [The Church and the Sami Minority]. (Acta Societatis Historicae Finlandiae Septentrionalis XIII.) Rovaniemi: Faravid.

Korhonen, S. (Ed.) (1975). Lapin kaunokirjallisuuden bibliografia [A bibliography on the fiction of Finland]. Rovaniemi: Pohjoiset Kirjailijat [Northern Writers].

Laufer, R. S., Freys-Wouters, E., \& Gallops, M. (1985). Traumatic stressors in the Vietnam War and post traumatic stress disorder. In C. R. Figley (Ed.). Trauma and its wake (pp. 74-89). New York: Brunner /Mazel.

Levinson, D. J. (1978). The seasons of man's life. New York: Ballantine.

Oinas, O. (2008). "Kauniit asiat ja ihmisten ilot eivät voi olla Jumalalle vieraita" Kirjailija ja pappi Arvi Järventaus ja Lappi ["Beauty and joy cannot be unacceptable to God" Author and clergyman Arvi Järventaus and Lapland]. (Acta Universitatis Lapponiensis No. 155.) Rovaniemi: University of Lapland.

Rosenthal, G. P. (1991). German war memories. Narrability and biographical and social functions of 
remembering oral history, 19, 34-37.

Rotschild, B. (1998). Post traumatic stress disorder. Swiss Journal of Social Work. 10. [Online] Available: http://www/home.webuniverse.net/art.diagnosis.htm (March 14, 2008).

Tuomaala, R. (2008). Kyllähän nyt pitäs olla jo semmonen aika, että pääsis niin kö keskustelemhan näistä asioista. Tutkimus lappilaisten huutolaisten, sotavankien ja partisaanien uhrien elämänkulusta, voimavaroista, terveydestä ja sairauksista [Research into the course of life, mental stamina and health status of wartime prisoners, victims of partisan attacks, and paupers in Finnish Lapland]. (Academic Dissertation. Ann. Univ. Turkuensis C, No. 274.) Turku: University of Turku.

\section{List of Primary Books of Arvi Järventaus mentioned in the text}

Järventaus, A. (1916). Risti ja Noitarumpu. Olaus Sirman tarina [The cross and the shaman drum, the story of Olaus Sirma]. Tampere: Kustannusosakeyhtiö Kirja.

Järventaus, A. (1917). Synnin mitta. Kertomus nykyaikaisesta Lapista [The measure of sin. A story about modern Lapland]. Tampere: Kustannusosakeyhtiö Kirja.

Järventaus, A. (1920). Satu Ruijan-maa [Fairy-tale Ruija-country]. Helsinki: Kustannusosakeyhtiö Kirja.

Järventaus, A. (1921). Tunturikertomuksia [Stories from the fells. Short stories]. Helsinki: Kustannusosakeyhtiö Kirja.

Järventaus, A. (1922). Kaukainen onni [Distant happiness, a story of a searcher for happiness]. Helsinki: Kustannusosakeyhtiö Kirja.

Järventaus, A. (1923). Ristilukki [The spider. Love story]. Helsinki: Kustannusosakeyhtiö Kirja.

Järventaus, A. (1924). Tunturien tuolta puolen. Novelleja [Stories from beyond the fells. Short stories]. Helsinki: Kustannusosakeyhtiö Kirja.

Järventaus, A. (1925). Maan Hiljaiset. Romaani suurten selkosten takaa [The silent of the earth. A novel from beyond the great wilderness]. Porvoo: WSOY.

Järventaus, A. (1927). Taivaallinen puuseppä. Romaani [A heavenly carpenter. Novel]. Porvoo: WSOY.

Järventaus, A. (1928). Tie selvä. [Road clear ahead]. Porvoo: WSOY.

Järventaus, A. (1937). Sydenpolttajat. Historiallinen romaani Unkarista 1700-luvun alkupuolelta[Coal burners. A historical novel from Hungary from the first decades of 18th century]. Porvoo: WSOY

Järventaus, A. (1939). Itkevien pajujen maa. Unkaria sieltä ja täältä [The land of the weeping willows. Hungary from here and there]. Porvoo: WSOY.

Järventaus, A. (2010). Magical Ruija - Magical Finnmark. (Transl. D. Lumijärvi \& M. Partanen.) Helsinki: Multiprint Oy.

Note

Note 1. Roland Barthes (1925-1989), a prominent French literary critic, philosopher and semiotician. 